1999

\title{
Do Historically Black Colleges and Universities Enhance the College Attendance of African American Youths?
}

Ronald G. Ehrenberg

Cornell University,rge2@cornell.edu

Donna S. Rothstein

Bureau of Labor Statistics

Robert B. Olsen

Mathematica Policy Research

Follow this and additional works at: http:// digitalcommons.ilr.cornell.edu/articles

Part of the Higher Education Commons, Labor Economics Commons, Labor Relations Commons, and the Race and Ethnicity Commons Thank you for downloading an article from DigitalCommons@ILR.

Support this valuable resource today!

This Article is brought to you for free and open access by the ILR Collection at DigitalCommons@ILR. It has been accepted for inclusion in Articles and Chapters by an authorized administrator of DigitalCommons@ILR. For more information, please contact hlmdigital@cornell.edu. 


\title{
Do Historically Black Colleges and Universities Enhance the College Attendance of African American Youths?
}

\begin{abstract}
Recently, Historically Black Colleges and Universities (HBCUs) have become the center of intense policy debates. Do HBCUs enhance the college attendance of African American youths? Previous research has been inconclusive. Among other improvements, our study adjusts for the relative availability of HBCU enrollment opportunities in each state. We find that African Americans are more likely to choose HBCUs over other colleges if more HBCU openings are available. However, more HBCU openings don't increase overall African American enrollment. As we have shown elsewhere, attendance at an HBCU does enhance African American students' college graduation rates.
\end{abstract}

\section{Keywords}

Historically Black Colleges and Universities, HBCUs, African American youth, higher education, graduation rates

\section{Disciplines}

Higher Education | Labor Economics | Labor Relations | Race and Ethnicity

\section{Comments}

\section{Suggested Citation}

Ehrenberg, R. G., Rothstein, D. S., \& Olsen, R. B. (1999). Do historically black colleges and universities enhance the college attendance of African American youths? [Electronic version]. In P. Moen, D. DempsterMcClain, \& H. A. Walker, (Eds.), A nation divided: Diversity, inequality, and community in American society (pp. 171-188). Ithaca, NY: Cornell University Press.

\section{Required Publisher Statement}

(C) Cornell University. Reprinted with permission. All rights reserved. 


\title{
C H A P T E M I M E
}

\section{Do Historically Black Colleges and Universities Enhance the College Attendance of African American Youths?}

\author{
Ronald G. Ehrenberg, Donna S. Rothstein, \\ and Robert B. Olsen
}

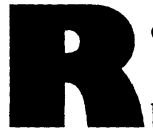

ecently, Historically Black Colleges and Universities (HBCUs) have become the center of intense policy debates. Do HBCUs enhance the college attendance of African American youths? Previous research has been inconclusive. Among other improvements, our study adjusts for the relative availability of HBCU enrollment opportunities in each state. We find that African Americans are more likely to choose HBCUs over other colleges if more HBCU openings are available. However, more HBCU openings don't increase overall African American enrollment. As we have shown elsewhere, attendance at an HBCU does enhance African American students' college graduation rates.

\section{Historically Black Colleges and Universities}

\section{The Rise and Decline of HBCUs}

Throughout most of the late nineteenth and early twentieth century, the majority of African American citizens lived and were educated in

Our research was funded by grants from the Andrew W. Mellon and William H. Donner Foundations and we are grateful to these organizations for their support. The views expressed here are solely those of the authors. 
the South. They were formally excluded from southern, segregated, white institutions of higher education and found higher educational opportunities only in the HBCUs. Some HBCUs (for example, Morehouse, Spelman, and Fisk) were private institutions that were initially established by church-related organizations. Others (for example, Florida A \& M, Grambling, and Morgan State) were public institutions established in the southern states after the Civil War to provide separate education for African American youths. The southern states established public HBCUs in order to meet the requirements of the second (1890) Morrill Act without allowing African Americans to attend the same institutions as whites. As part of providing funding for land-grant institutions, the act required that the states provide educational opportunities for all of their citizens.

As the African American population began to move to the North in response to urban industrial employment opportunities, the relative importance of the HBCUs for the education of African American college-age students began to decline. The famous 1954 Brown v. Board of Education U.S. Supreme Court decision, which outlawed separate but equal public schools, actually had very little impact on many of the southern states, and formally segregated higher educational systems remained. When integrated at all, the white institutions often did so only as a result of suits pursued by the National Association for the Advancement of Colored People (NAACP). ${ }^{1}$ It was not until the passage of the 1964 Civil Rights Act, Title VI of which prohibited the allocation of federal funds to segregated public educational institutions, that any real progress toward integration was made. However, this progress was very slow, and in a 1973 U.S. Supreme Court decision, Adams $v$. Richardson, the southern states were formally and finally ordered to dismantle their dual higher educational systems.

As recently as 1964, over half of all bachelor's degrees granted to African Americans were granted by HBCUs. By 1973, with the continued African American migration to the North and the beginnings of integrated higher education in the South, the HBCU share of African American bachelor's degrees had fallen to between one-fourth and one-third, the range in which it remains today. Over 90 percent of the HBCU institutions are four-year institutions and over 95 percent of the students enrolled in HBCUs attend four-year institutions. While more HBCUs are private than public, the former are often quite small and about three-fourths of the students at HBCUs are enrolled in public institutions. Approximately 20 percent of all African American college students are now enrolled in the HBCUs (Hoffman, Snyder, and Sonnenberg 1992). This latter share is less than the HBCU share of African American bachelor's degrees for two reasons: African American

${ }^{1}$ Many of these are vividly described in Rowan (1993). 
enrollments in non-HBCU two-year institutions and higher graduation rates for African American students who attend four-year HBCUs than for those who attend other four-year colleges (Ehrenberg and Rothstein 1994).

\section{Policy Debates Surrounding HBCUs}

Despite the declining relative importance of the HBCUs in the production of African American bachelor's degrees, they have become the subject of intense public policy debate in recent years. Court cases have been filed in a number of southern states, cases that assert that African American students continue to be underrepresented at traditionally white public institutions, that discriminatory admissions criteria are used by these institutions to exclude African American students (e.g., basing admissions only on test scores and not also on grades), and that per student funding levels, program availability, and library facilities are substantially poorer at the public HBCUs than at other public institutions in the state. In one 1992 case, United States $v$. Fordice, the U.S. Supreme Court ruled that Mississippi had not done enough to eliminate racial segregation in its state-run higher educational institutions. Rather than mandating a remedy, however, the Court sent the case back to the Federal District Court for action.

In March of 1995, Federal District Court judge Neal B. Biggers responded to the state proposal by ruling that Mississippi could not close public HBCUs near historically white colleges or universities (or close historically white colleges or universities near HBCUs) as a way of eliminating racial segregation in college enrollments. Rather, he ordered the state to spend more money to establish new graduate programs at two HBCUs (Jackson and Alcorn State) to enhance their attractiveness to white students, as well as to establish endowments at these two institutions to provide scholarship funds to attract white students (Smothers 1995). In addition, he ordered the three public HBCUs in the state to raise their admission standards to levels comparable to those at other public institutions in the state and ordered the state to finance remedial programs that would assist students who did not meet the higher standards to achieve admission to the public institutions. The adoption of the tougher admission standards were subsequently deferred until the 1996-97 academic year (Healy 1995a).

The increase in admission standards at HBCUs in Mississippi and proposals for similar changes in other southern states have led to substantial concern in the African American community (Healy 1995b, 1996a). While proponents of the higher admission standards argue that they will lead to enhanced education in terms of courses taken, grades, and test scores, critics fear that they will lead to drastic declines in enrollments in HBCUs and to a decline in higher educational opportunities for African American 
youths in general, especially disadvantaged youths. That is, they assert that the presence of HBCUs in southern states enhances African American students' college enrollment probabilities and that the higher admission standards will weaken HBCUs and thus diminish African American students' college enrollment rates. African American freshman enrollments did decline by 9 percent in Mississippi public universities in 1996 and 1997; many attributed this to the new higher admissions standards (Healy 1996b). ${ }^{2}$

\section{Prior Research and Background Data}

Have HBCUs enhanced the probability that African American high school graduates will enroll in postsecondary education? Proponents of strengthening HBCUs argue that they have. They point to evidence that historically, after controlling for other factors, the proportion of African Americans enrolled in college was higher in states in which HBCUs were present than it was in other states (Brazziel and Brazziel 1980).

Such comparisons-even with contemporary data-are not particularly useful, however, because they do not disentangle the effects of HBCUs per $s e$ from the effects of other variables that differ across states and influence college-going behavior. These may include the quality of the high school educations received by African Americans, their high school graduation rates, their families' incomes, and their parents' education levels and aspirations. For example, suppose that high school graduates from families in which parents have gone to college are more likely to go to college than graduates from families in which parents have less education. Suppose also that the proportion of African American parents with college educations is higher in states with HBCUs. It may be the variation in parents' education levels, not whether an HBCU is present in the state, that "causes" the observed interstate variation. ${ }^{3}$

\section{A Previous Study by Constantine}

To avoid this problem, Constantine (1995) used data from the National Longitudinal Study of the High School Class of 1972 (henceforth NLS72) to model the college enrollment decisions of African American

\footnotetext{
2 This decline in African American enrollments led to an appeal to the U.S. Supreme Court in late 1997 that the Court revisit their Fordice decision. However, the Court declined to revisit the case (Lederman 1998).

3 Of course, one may argue that higher African American parental education levels in states with HBCUs are due to the impact that HBCUs had on college enrollment rates in a previous generation. This interpretation is entirely consistent with our point. At issue is whether the presence of HBCUs today enhances African American college enrollment rates today, not what their effects were in the past.
} 
high school graduates. NLS72 is a national probability sample of approximately 22,000 students who graduated from high school in 1972, over 3,000 of whom were African Americans. ${ }^{4}$ These individuals were surveyed five more times, in 1973, 1974, 1976, 1979, and 1986. The last survey included only about two-thirds of the original sample (primarily for financial reasons) and college graduates were disproportionately surveyed in this follow-up. Constantine analyzed the data for 1,192 respondents for whom she also had observations on earnings in 1986.

She divided respondents' postsecondary educational decision into three groups: attend a four-year HBCU; attend another four-year college; or don't attend any four-year college. She included decisions made within the first three years after high school graduation. She estimated a multinomial logit model in which the outcome chosen was specified to depend on the individual's ability, other individual characteristics, family characteristics, characteristics of the student's high school, and a number of state-specific variables, including whether the state had at least one public HBCU.

Constantine's results suggest that the presence of public HBCUs in a state had three effects: it increased the probability that a student would enroll in a four-year HBCU by about .12; it had virtually no effect on the probability that a student would enroll in another four-year college; and it decreased the probability that a student would not enroll in a four-year college. Because the latter category includes both enrollees in two-year colleges and noncollege enrollees, she concluded that the presence of public HBCUs draws into four-year HBCUs those students who would have otherwise attended a two-year institution or not attended any college. If it were the latter, one could conclude that the presence of HBCUs increased the sum African American enrollments in two- and four-year colleges in the 1970s. However, because Constantine grouped two-year college enrollees and non-enrollees together, she could not draw this conclusion.

Moreover, to say that there is a public HBCU in a state tells one little about the opportunities HBCUs provide relative to the number of African American high school graduates who may desire to attend them. Consider the following hypothetical example: Suppose that there are two states and that each has five thousand African American high school graduates a year and a single public HBCU. Suppose further that the HBCU in the first state has a capacity of one thousand first-year students, while that in the second is much smaller and has a capacity of one hundred first-year students. Intuition suggests that, other things being equal, African American college enrollments will be higher in the first state. Put another way, it is not the presence of

\footnotetext{
${ }^{4}$ See Research Triangle Institute (1981) for a description of NLS72.
} 
Table 9.1. Full-time equivalent undergraduate enrollments at Historically Black Colleges and Universities in a state relative to four times the number of African American high school seniors in the state (SLOTS)

\begin{tabular}{lcc}
\hline & SLOTS72 $^{\mathrm{a}}$ & SLOTS80 $^{\mathrm{a}}$ \\
\hline Alabama & .167 & .084 \\
Arkansas & .128 & .079 \\
Delaware & .414 & .223 \\
District of Columbia & .314 & .204 \\
Florida & .096 & .043 \\
Georgia & .143 & .048 \\
Kentucky & .086 & .079 \\
Louisiana & .203 & .142 \\
Maryland & .181 & .104 \\
Mississippi & .198 & .149 \\
Missouri & .106 & .077 \\
North Carolina & .200 & .137 \\
Ohio & .048 & .024 \\
Oklahoma & .091 & .082 \\
Pennsylvania & .046 & .032 \\
South Carolina & .091 & .043 \\
Tennessee & .180 & .093 \\
Texas & .146 & .077 \\
Virginia & .215 & .130 \\
West Virginia & .505 & .886 \\
\hline Meanb & .153 & .094 \\
Standard Deviation & .069 & .111 \\
\hline
\end{tabular}

aSLOTS72 is based on 1972 Higher Education General Information Survey (HEGIS) (enrollment) and U.S. Bureau of the Census 1970 Census of Population (number of seniors) data; SLOTS80 is based on 1980 HEGIS and U.S. Bureau of the Census 1980 Census of Population data.

bMean and standard deviations are across individuals in the National Longitudinal Study of the High School Class of 1972 (NLS72) and High School and Beyond Survey (HSB) samples, not across states.

HBCUs in a state per se, but rather their size relative to the number of African American high school graduates that should influence the probability that an African American high school graduate goes on to college.

\section{Adjusting for HBCU "SLOTS"}

Does significant variation in the relative availability of enrollment opportunities in HBCUs actually occur across states in which HBCUs are present? Table 9.1 presents data, by state, on the ratio of the number of full-time equivalent undergraduate enrollments in all HBCUs in the state to four times the number of African American high school seniors in the state (SLOTS) for both 1972 and 1980. The denominator is multiplied by four so that the resulting ratio approximates the fraction of African Amer- 
ican high school seniors for whom there is space in HBCUs in the state. While some HBCUs operated at less than full capacity during these years, capacity (as opposed to enrollment) data are not available. Total HBCU enrollments are used rather than public enrollments because private HBCUs follow a low-tuition policy to maintain their accessibility to lowincome students. ${ }^{5}$ In practice, this distinction does not matter. Using public enrollments in the numerator yielded similar results in the econometric estimation that follows in the next section. Finally, the number of high school seniors rather than the number of high school graduates is used in the denominator because the availability of positions in HBCUs may affect the effort put forth by high school seniors to complete high school.

The data in Table 9.1 suggests that the scale of HBCUs relative to the number of African American high school seniors varied widely across states that had HBCUs in both 1972 and 1980. In 1972, the ratio, henceforth SLOTS, ranged from under .05 in Pennsylvania and Ohio to over .5 in West Virginia. The mean value of SLOTS faced by African American high school seniors present in the NLS72 data was .153. By 1980, the mean value of SLOTS faced by seniors in the High School and Beyond survey (henceforth HSB), a national probability sample of students who graduated from high school in the early 1980s and is comparable to NLS72, fell to .094, with the value of SLOTS ranging from .02 in Ohio to more than .8 in West Virginia.

The West Virginia number is not an error. By 1980 African American students made up less than 15 percent of the enrolled students at the two HBCUs in West Virginia, West Virginia State and Bluefield State (Hill 1984) ${ }^{6}$ However, because educational opportunities were available for African Americans at these HBCUs, we believe that the value of SLOTS for African Americans in West Virginia accurately represents their opportunity to attend an HBCU. ${ }^{7}$

\section{Analytical Approach}

The discussion above and the data on the variation in SLOTS suggest that rather than focusing on differences in African American college enrollment decisions between states that have and those that do not have

${ }^{5}$ For example, in 1992 and 1993 average tuition and fees were $\$ 5,008$ at the 41 private United Negro College Fund schools, less than half the national average for private schools (Fordyce 1993).

${ }^{6}$ For example, between 1970 and 1980 alone, African American high school enrollment in West Virginia fell from 6,113 to 5,260, a decline of 14 percent (U.S. Bureau of the Census 1973, Table 51; U.S. Bureau of the Census 1983, Table 76). The evolution of these schools into predominantly white institutions predates the 1970s.

7 An alternative is to simply exclude the small number of African American students in West Virginia from the samples we use for the analysis. The two methods yielded similar results. 
HBCUs, we should instead focus on how college enrollment decisions differ across states in which HBCUs are present, with an emphasis on the role of the relative availability of slots for first-year students in HBCUs. That is, we should ask how differences in SLOTS across states influence college enrollment decisions.

We do this in a manner analogous to Constantine's by estimating multinomial logit models of the college enrollment decision of African Americans. However, our analyses differ from hers in a number of important ways. First, we use data from both the NLS72 and HSB to see whether the effects of HBCUs on enrollments have varied over time.

Second, we estimate models with four possible outcomes rather than the three-outcome model that Constantine used. High school seniors are assumed to choose between enrolling in a four-year HBCU, enrolling in another four-year college, enrolling in a two-year college that offers degree programs, or not enrolling in a college. This enables us to ascertain if HBCUs did affect the aggregate (two-year plus four-year) African American college enrollment rate in 1972 and 1980.

Third, and perhaps most crucially, we restrict our attention to students who graduated from high school in states in which HBCUs are present. We focus on how the value of SLOTS influences the students' choice of college and college-going behavior. Again, SLOTS is the ratio of full-time equivalent undergraduate enrollments in HBCUs in the state relative to four times the number of African American high school seniors in the state, a measure of the relative availability of positions in HBCUs. We are careful to indicate, however, how results differ when we include individuals in the sample who graduated from high school in states without HBCUs, and we assign them a value of zero for SLOTS.

Finally, unlike Constantine, we do not restrict our analyses of NLS72 to the subset of students who were present in the 1986 follow-up and for whom wage data were available. As indicated above, her sample was a nonrandom subsample of the original sample. In particular, four-year college graduates were disproportionately represented in the 1986 follow-up and this "choice-based" sampling may lead to inconsistent estimates. ${ }^{8}$ Rather, for both NLS72 and HSB we analyze the decisions of all individuals who were present in the sample three years after their high school graduation. When we use HSB, we also analyze the decisions of people six years after

8 When the probability of being in a sample is related to the outcome under study (that is, "choice-based sampling") inconsistent estimates may occur. See Manski and Lerman (1977). The problem arises in Constantine's sample because to be a four-year college graduate one had to have been enrolled in a four-year college. Because four-year college graduates were disproportionately included in her sample, so were four-year college enrollees. 
high school graduation to see if including delayed college entrants alters any of our conclusions.

\section{Empirical Findings}

Using both NLS72 and HSB, we estimated multinomial models of African American high school graduates' decisions to enroll in four-year HBCUs, enroll in other four-year colleges, enroll in a two-year college, or not enroll in college within their first three years after high school graduation. An individual who had ever enrolled in a four-year HBCU during the period was classified as enrolled in an HBCU. An individual who had ever enrolled in a four-year college, but had not enrolled in a four-year HBCU, was classified as enrolled in an other four-year college. An individual who had ever enrolled in a two-year college during the period, but was never enrolled in a four-year college during the period, was classified as enrolled in a two-year college. An individual's choice of college sector was specified to be a function of his or her individual characteristics, family characteristics (such as parents' education and income), high school characteristics, distance to the nearest two- and four-year colleges, and the SLOTS variable in his or her state. Complete tables of coefficient estimates and definitions of all of the explanatory variables are available from the first author.

\section{A Preference for $\mathrm{HBCUs}$}

Our empirical findings are similar for the two data sets. Students from states with large SLOTS values are more likely to attend HBCUs and less likely to attend other four-year or two-year colleges than students from states with small SLOTS values. Put another way, African American high school graduates are more likely to attend HBCUs rather than other colleges when positions in HBCUs are available to them.

Table 9.2 summarizes simulations we conducted to give a sense of the magnitudes of these effects. These simulations use the NLS72 estimates and values of the data for each individual. In panel A, we focus on all of the African American high school graduates from states in which an HBCU was present in the sample. Row 1 indicates that within three years of high school graduation, 19.3 percent of them enrolled in four-year HBCUs, 16.6 percent enrolled in other four-year colleges, and 12.9 percent enrolled in two-year colleges. Row 2 shows the predicted enrollment percentages in each category obtained using the estimated coefficients and the values of the explanatory variables for each individual. The predictions of the model are virtually identical to what actually occurred and were used as the baseline in what follows.

Row 3 indicates the predictions of the model if we increase the value of SLOTS in each individual's state by one standard deviation of its variation 
Table 9.2. Simulated effects of increasing the ratio of full-time equivalent enrollments at Historically Black Colleges and Universities (HBCUs) in a state relative to the number of African American seniors in the state by one standard deviation: National Longitudinal Study of the Class of 1972

\begin{tabular}{|c|c|c|c|c|}
\hline & $\begin{array}{l}\text { Enrolled in } \\
\text { Four-Year } \\
\text { HCBU (\%) }\end{array}$ & $\begin{array}{l}\text { Enrolled in } \\
\text { Other } \\
\text { Four-Year } \\
(\%)\end{array}$ & $\begin{array}{l}\text { Enrolled in } \\
\text { Two-Year } \\
(\%)\end{array}$ & $\begin{array}{l}\text { Other } \\
(\%)\end{array}$ \\
\hline \multicolumn{5}{|c|}{$\begin{array}{c}\text { Panel A } \\
\text { All African Americans }\end{array}$} \\
\hline $\begin{array}{l}\text { I Actual } \\
2 \text { Predicted by Model } \\
3 \text { Predicted If HBCU Slots Increase } \\
4 \text { Change (row } 3 \text { minus row } 2)^{b}\end{array}$ & $\begin{array}{r}19.3 \\
19.2 \\
28.6 \\
9.4\end{array}$ & $\begin{array}{r}16.6 \\
16.7 \\
8.8 \\
-7.8\end{array}$ & $\begin{array}{l}12.9 \\
12.9 \\
10.8 \\
-2.0\end{array}$ & $\begin{array}{r}51.2 \\
51.2 \\
51.7 \\
0.5\end{array}$ \\
\hline \multicolumn{5}{|c|}{$\begin{array}{c}\text { Panel B } \\
\text { Bottom-Quartile Test Score }\end{array}$} \\
\hline $\begin{array}{l}\text { I Actual } \\
2 \text { Predicted by Model } \\
3 \text { Predicted If HBCU Slots Increase } \\
4 \text { Change (row } 3 \text { minus row } 2 \text { ) }\end{array}$ & $\begin{array}{r}7.8 \\
10.1 \\
14.7 \\
4.5\end{array}$ & $\begin{array}{r}5.0 \\
4.8 \\
2.4 \\
-2.4\end{array}$ & $\begin{array}{l}13.2 \\
13.8 \\
11.4 \\
-2.3\end{array}$ & $\begin{array}{r}73.9 \\
71.3 \\
71.6 \\
0.2\end{array}$ \\
\hline \multicolumn{5}{|c|}{$\begin{array}{c}\text { Panel C } \\
\text { Bottom-Quartile Family Income }\end{array}$} \\
\hline $\begin{array}{l}\text { I Actual } \\
2 \text { Predicted by Model } \\
3 \text { Predicted If HBCU Slots Increase } \\
4 \text { Change (row } 3 \text { minus row } 2 \text { ) }\end{array}$ & $\begin{array}{r}17.4 \\
17.6 \\
25.8 \\
8.1\end{array}$ & $\begin{array}{r}14.8 \\
11.7 \\
5.8 \\
-5.9\end{array}$ & $\begin{array}{l}11.6 \\
12.6 \\
10.4 \\
-2.1\end{array}$ & $\begin{array}{r}56.2 \\
58.0 \\
57.9 \\
-0.1\end{array}$ \\
\hline
\end{tabular}

aColumn totals do not always add to 100 in rows 1,2 , and 3 and to zero in rows 4 due to rounding errors.

'Authors' computations from multinomial logit model estimates (which are available from the first author) and the values of the explanatory variables for each individual.

across individuals (or .069). That is, it indicates how increasing the availability of positions in HBCUs in the state relative to the number of African American high school seniors would influence the seniors' enrollment probabilities. Because the mean value of SLOTS across individuals in the sample was .153, this represents a substantial increase. Row 4 , which is simply the difference between rows 3 and 2, indicates the predicted change that would occur.

Quite strikingly, we predict the probability of a student attending an HBCU to increase by 9.4 percent, an almost 50 percent increase in enrollments at HBCUs. However, none of this increase would come from students who were currently not enrolled in college. Rather, it reflects a large 
shift, 7.8 percent, of students from other four-year colleges and a smaller shift, 2.0 percent, of students from two-year colleges. Put another way, we predict that increasing the number of HBCU slots does not increase the aggregate African American enrollment rate. ${ }^{9}$

It is well known that students who initially enroll in two-year colleges are much less likely to graduate eventually from a four-year institution than students who initially enroll in four-year institutions. ${ }^{10}$ Moreover, our own previous research provides strong evidence that HBCUs enhance graduation rates of African American four-year college students (Ehrenberg and Rothstein 1994). Hence, although these results suggest that HBCUs do not enhance the probability that an African American enrolls in college, they do enhance enrollees' chances of graduating from a four-year college.

\section{Adjusting for Economic and Educational Disadvantages}

Supporters of HBCUs often argue that HBCUs are particularly important to economically and educationally disadvantaged African American youth. Their relatively low tuitions, both in the public and private sectors, are believed to make it possible for economically disadvantaged youth to gain access to higher education. Their provision of remedial education and a supportive environment, along with their willingness to take a chance and admit students who perform poorly on standardized admission tests, is believed to enhance the college enrollment rates of educationally disadvantaged students.

Is there evidence to support these arguments in our data? Panels B and $\mathrm{C}$ of Table 9.2 repeat the simulations performed in panel $\mathrm{A}$, but restrict the samples used in the simulation to individuals who came from the bottom quartiles of the test score and family income distributions, respectively, for African American youth in NLS72. ${ }^{11}$ The "actual" rows are now the proportions of African American high school students in each group who choose each outcome. Not surprisingly, low test scores substantially reduce the aggregate college enrollment rate and the probability of being enrolled in any four-year college (compare row A1 with row B1). However, being in the bottom quartile of the family income distribution reduces college enrollment by a much smaller amount (compare row $\mathrm{A} 1$ with row $\mathrm{C} 1$ ).

Simulations of the effects of increasing SLOTS on the enrollment behavior of these subsets of individuals (rows B4 and C4) provide very sim-

\footnotetext{
9 The aggregate college enrollment rate for the group is simply the sum of the three enrollment percentages, or equivalently one hundred minus the "other" percentage.

${ }_{10}$ See Clotfelter et al. (1991), Table 2.18, for example.

11 The test scores are a weighted sum of scaled test scores on three sections (mathematics plus one-half the sum of reading and vocabulary) given to NLS72 respondents.
} 
Table 9.3. Simulated effects of increasing the ratio of full-time equivalent enrollments at Historically Black Colleges and Universities (HBCUs) in a state relative to the number of African American seniors in the state by one standard deviation: $1980 \mathrm{High} \mathrm{School} \mathrm{and} \mathrm{Beyond} \mathrm{Senior} \mathrm{Cohort}$

\begin{tabular}{|c|c|c|c|c|}
\hline & $\begin{array}{l}\text { Enrolled in } \\
\text { Four-Year } \\
\text { HCBU (\%) }\end{array}$ & $\begin{array}{l}\text { Enrolled in } \\
\text { Other } \\
\text { Four-Year } \\
\text { (\%) }\end{array}$ & $\begin{array}{l}\text { Enrolled in } \\
\text { Two-Year } \\
(\%)\end{array}$ & $\begin{array}{l}\text { Other } \\
(\%)\end{array}$ \\
\hline \multicolumn{5}{|c|}{$\begin{array}{c}\text { Panel A } \\
\text { All African Americans }\end{array}$} \\
\hline $\begin{array}{l}\text { I Actual } \\
2 \text { Predicted by Model } \\
3 \text { Predicted If HBCU Slots Increase } \\
4 \text { Change (row } 3 \text { minus row } 2)^{b}\end{array}$ & $\begin{array}{r}18.5 \\
18.5 \\
23.8 \\
5.3\end{array}$ & $\begin{array}{r}20.5 \\
20.6 \\
16.3 \\
-4.3\end{array}$ & $\begin{array}{r}16.2 \\
16.2 \\
14.3 \\
-1.9\end{array}$ & $\begin{array}{r}44.8 \\
44.8 \\
45.6 \\
0.8\end{array}$ \\
\hline \multicolumn{5}{|c|}{$\begin{array}{c}\text { Panel B } \\
\text { Bottom-Quartile Test Score }\end{array}$} \\
\hline $\begin{array}{l}\text { I Actual } \\
2 \text { Predicted by Model } \\
3 \text { Predicted If HBCU Slots Increase } \\
4 \text { Change (row } 3 \text { minus row } 2 \text { ) }\end{array}$ & $\begin{array}{r}14.4 \\
13.8 \\
17.8 \\
4.0\end{array}$ & $\begin{array}{r}10.8 \\
12.3 \\
9.4 \\
-2.9\end{array}$ & $\begin{array}{l}19.3 \\
18.7 \\
16.6 \\
-2.1\end{array}$ & $\begin{array}{r}55.5 \\
55.2 \\
56.3 \\
1.1\end{array}$ \\
\hline \multicolumn{5}{|c|}{$\begin{array}{c}\text { Panel C } \\
\text { Bottom-Quartile Family Income }\end{array}$} \\
\hline $\begin{array}{l}\text { I Actual } \\
2 \text { Predicted by Model } \\
3 \text { Predicted If HBCU Slots Increase } \\
4 \text { Change (row } 3 \text { minus row } 2 \text { ) }\end{array}$ & $\begin{array}{r}19.4 \\
18.4 \\
23.4 \\
5.0\end{array}$ & $\begin{array}{r}13.8 \\
13.0 \\
9.8 \\
-3.2\end{array}$ & $\begin{array}{l}16.6 \\
15.3 \\
13.2 \\
-2.1\end{array}$ & $\begin{array}{r}50.2 \\
53.4 \\
53.6 \\
-0.2\end{array}$ \\
\hline
\end{tabular}

aColumn totals do not always add to 100 in rows 1,2 , and 3 and to zero in rows 4 due to rounding errors.

'Authors' computations from multinomial logit model estimates (which are available from the first author) and the values of the explanatory variables for each individual.

ilar results to those described in panel A. Increasing SLOTS has virtually no impact on the overall college enrollment rate for each group. Rather, an increased availability of positions in HBCUs again simply shifts enrolled students from two-year and other four-year to four-year HBCU schools. These results suggest that HBCUs do not yield extra benefits, in terms of their effects on initial enrollment probabilities, to economically and educationally disadvantaged youth above and beyond what they yield to other African American youths.

Do the results we found for 1972 using NLS72 data continue to hold in later years? Table 9.3 presents the results of similar simulations for African 
American high school seniors in 1980. These simulations use individual data from HSB and the estimated multinomial logit model for 1980. Comparing rows $\mathrm{A} 1$ of Tables 9.2 and 9.3, one observes that the actual African American high school senior college enrollment rate (within three years of high school graduation and in states with HBCUs) increased between 1972 and 1980 from about 48.8 to 55.2 percent in the data. However, the enrollment rate at four-year HBCUs fell from 19.3 to 18.5 percent.

Focusing next on the predicted changes in the enrollment rates presented in row A4, if we increase SLOTS by one standard deviation (which in 1980 was .109) we observe the same qualitative results as in the 1972 data. Enrollments in four-year HBCUs are predicted to increase, but all of this increase comes from predicted declines in other four-year college enrollments and two-year college enrollments. Put another way, the simulation predicts no increase in the aggregate college enrollment rate. Finally, panels B and C, which repeat the simulations for educationally and economically disadvantaged students, again reiterate the 1972 findings, namely, that the impact of increased availability of HBCU slots relative to the number of African American high school seniors is about the same for educationally and economically disadvantaged seniors as it is for other African American high school seniors.

\section{Using Other Specifications and Samples}

We conducted a number of additional simulations to see how sensitive our 1980 HSB findings are to alternative specifications and samples. Table 9.4 is based on enrollment decisions made during the first six years rather than the first three years after high school. Not surprisingly, a higher percentage of African American high school seniors in HSB had enrolled in some form of college within six years after high school graduation (62.5 percent) than had done so within three years (55.2 percent). However, the simulation results shown in the table (which are based on a multinomial logit model estimated using the six-year data) are very similar to those reported previously. The effects of slots in HBCUs on college enrollment decisions does not vary between early (first three years after high school) and later (years four through six) enrollees.

Table 9.5 reports simulations performed separately for African American males and females. Rows A1 and B1 of the table suggest that the overall college enrollment rate was higher for the females than for the males in 1980 and that females were also slightly more likely to attend HBCUs that year. As the table notes indicate, the underlying model that was estimated allowed an individual's gender to affect directly the enrollment choice decision and it also allowed the effects of SLOTS to vary with gen- 
Table 9.4. Simulated effects of increasing the ratio of full-time equivalent enrollments at Historically Black Colleges and Universities (HBCUs) in a state relative to the number of African American seniors in the state by one standard deviation: 1980 High School and Beyond Senior Cohort, six years post-high school

\begin{tabular}{|c|c|c|c|c|}
\hline & $\begin{array}{l}\text { Enrolled in } \\
\text { Four-Year } \\
\text { HCBU (\%) }\end{array}$ & $\begin{array}{l}\text { Enrolled in } \\
\text { Other } \\
\text { Four-Year } \\
\quad(\%)\end{array}$ & $\begin{array}{l}\text { Enrolled in } \\
\text { Two-Year } \\
(\%)\end{array}$ & $\begin{array}{l}\text { Other }^{\mathrm{a}} \\
(\%)\end{array}$ \\
\hline \multicolumn{5}{|c|}{$\begin{array}{c}\text { Panel A } \\
\text { All African Americans }\end{array}$} \\
\hline $\begin{array}{l}\text { I Actual } \\
2 \text { Predicted by Model } \\
3 \text { Predicted If HBCU Slots Increase } \\
4 \text { Change (row } 3 \text { minus row } 2)^{b}\end{array}$ & $\begin{array}{r}20.6 \\
20.7 \\
26.8 \\
6.1\end{array}$ & $\begin{array}{l}23.4 \\
23.2 \\
18.0 \\
-5.2\end{array}$ & $\begin{array}{l}18.5 \\
18.5 \\
15.7 \\
-2.8\end{array}$ & $\begin{array}{r}37.5 \\
37.6 \\
39.5 \\
1.9\end{array}$ \\
\hline \multicolumn{5}{|c|}{$\begin{array}{c}\text { Panel B } \\
\text { Bottom-Quartile Test Score }\end{array}$} \\
\hline $\begin{array}{l}\text { I Actual } \\
2 \text { Predicted by Model } \\
3 \text { Predicted If HBCU Slots Increase } \\
4 \text { Change (row } 3 \text { minus row } 2 \text { ) }\end{array}$ & $\begin{array}{r}15.5 \\
14.8 \\
19.3 \\
4.5\end{array}$ & $\begin{array}{l}14.1 \\
15.9 \\
12.1 \\
-3.8\end{array}$ & $\begin{array}{l}21.8 \\
21.9 \\
18.6 \\
-3.3\end{array}$ & $\begin{array}{r}48.6 \\
47.5 \\
50.0 \\
2.5\end{array}$ \\
\hline \multicolumn{5}{|c|}{$\begin{array}{c}\text { Panel C } \\
\text { Bottom-Quartile Family Income }\end{array}$} \\
\hline $\begin{array}{l}\text { I Actual } \\
2 \text { Predicted by Model } \\
3 \text { Predicted If HBCU Slots Increase } \\
4 \text { Change (row } 3 \text { minus row } 2 \text { ) }\end{array}$ & $\begin{array}{r}20.6 \\
20.8 \\
26.4 \\
5.6\end{array}$ & $\begin{array}{r}14.6 \\
13.6 \\
9.9 \\
-3.7\end{array}$ & $\begin{array}{l}19.4 \\
18.1 \\
14.9 \\
-3.2\end{array}$ & $\begin{array}{r}45.5 \\
47.5 \\
48.8 \\
1.3\end{array}$ \\
\hline
\end{tabular}

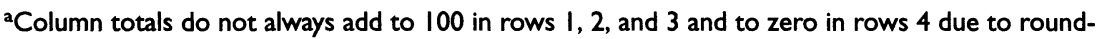
ing errors.

'Authors' computations from multinomial logit model estimates (which are available from the first author) and the values of the explanatory variables for each individual.

der. However, the simulations do not yield large differences in results. In both cases, an increase in SLOTS does increase enrollments in four-year HBCUs, but it also decreases enrollments in other two-year and four-year colleges and produces no overall increase in enrollments.

A third simulation addresses possible concerns that our underlying enrollment-choice model included SLOTS but did not control for enrollment opportunities in other four-year colleges in the state. We computed the ratio of full-time equivalent undergraduate enrollments in other four-year colleges in a state divided by four times the total number of high school seniors in the state, reestimated the multinomial logit model 
Table 9.5. Simulated effects of increasing the ratio of full-time equivalent enrollments at Historically Black Colleges and Universities (HBCUs) in a state relative to the number of African American seniors in the state by one standard deviation: 1980 High School and Beyond Senior Cohort, by gender

\begin{tabular}{|c|c|c|c|c|}
\hline & $\begin{array}{l}\text { Enrolled in } \\
\text { Four-Year } \\
\text { HCBU (\%) }\end{array}$ & $\begin{array}{l}\text { Enrolled in } \\
\text { Other } \\
\text { Four-Year } \\
(\%)\end{array}$ & $\begin{array}{c}\text { Enrolled in } \\
\text { Two-Year } \\
(\%)\end{array}$ & $\begin{array}{l}\text { Other } \\
(\%)\end{array}$ \\
\hline \multicolumn{5}{|c|}{$\begin{array}{c}\text { Panel A } \\
\text { African American Males }\end{array}$} \\
\hline $\begin{array}{l}\text { I Actual } \\
2 \text { Predicted by Model } \\
3 \text { Predicted If HBCU Slots Increase } \\
4 \text { Change (row } 3 \text { minus row } 2)^{b}\end{array}$ & $\begin{array}{r}17.9 \\
17.9 \\
25.2 \\
7.3\end{array}$ & $\begin{array}{l}20.7 \\
20.6 \\
13.9 \\
-6.7\end{array}$ & $\begin{array}{r}15.3 \\
15.3 \\
13.0 \\
-2.3\end{array}$ & $\begin{array}{r}46.2 \\
46.2 \\
47.8 \\
1.6\end{array}$ \\
\hline \multicolumn{5}{|c|}{$\begin{array}{c}\text { Panel B } \\
\text { African American Females }\end{array}$} \\
\hline $\begin{array}{l}\text { I Actual } \\
2 \text { Predicted by Model } \\
3 \text { Predicted If HBCU Slots Increase } \\
4 \text { Change (row } 3 \text { minus row } 2 \text { ) }\end{array}$ & $\begin{array}{r}18.9 \\
18.9 \\
24.5 \\
5.6\end{array}$ & $\begin{array}{r}20.5 \\
20.4 \\
16.5 \\
-3.9\end{array}$ & $\begin{array}{r}16.9 \\
16.9 \\
14.7 \\
-2.2\end{array}$ & $\begin{array}{r}43.8 \\
43.8 \\
44.3 \\
0.5\end{array}$ \\
\hline
\end{tabular}

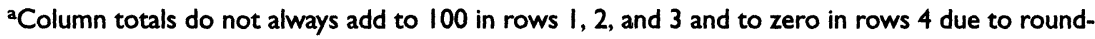
ing errors.

'Authors' computations from multinomial logit model estimates (which are available from the first author) and the values of the explanatory variables for each individual.

including this additional variable, and then conducted simulations using these new estimates. These simulations again suggest that an increase in SLOTS does lead to an increase in enrollments at four-year HBCUs, but in this model the increase appears to be fully offset by a decrease in other fouryear college enrollments. Again there is no increase in the overall enrollment rate and no additional effect on the college enrollment behavior of students with lower test scores or lower family incomes.

Finally, we estimated the enrollment-choice model using the HSB data for African American high school seniors in all states, not simply those in states with HBCUs, assigning a value of zero to SLOTS in states without HBCUs. We then again simulated what the effect of increasing SLOTS would be on the college enrollment decisions of African American youths. One reason for conducting these final simulations is that some people believe that the effects of HBCUs can best be estimated by making comparisons between HBCU and non-HBCU states, as well as by making comparisons across the HBCU states. As indicated above, we do not subscribe to this viewpoint. 
Table 9.6. Simulated effects of increasing the ratio of full-time equivalent enrollments at Historically Black Colleges and Universities (HBCUs) in a state relative to the number of African American seniors in the state by one standard deviation: $1980 \mathrm{High} \mathrm{School} \mathrm{and} \mathrm{Beyond} \mathrm{Senior} \mathrm{Cohort,} \mathrm{all} \mathrm{states}$

\begin{tabular}{|c|c|c|c|c|}
\hline & $\begin{array}{l}\text { Enrolled in } \\
\text { Four-Year } \\
\text { HCBU (\%) }\end{array}$ & $\begin{array}{l}\text { Enrolled in } \\
\text { Other } \\
\text { Four-Year } \\
\text { (\%) }\end{array}$ & $\begin{array}{c}\text { Enrolled in } \\
\text { Two-Year } \\
\text { (\%) }\end{array}$ & $\begin{array}{l}\text { Other } \\
(\%)\end{array}$ \\
\hline \multicolumn{5}{|c|}{$\begin{array}{c}\text { Panel A } \\
\text { All African Americans }\end{array}$} \\
\hline $\begin{array}{l}\text { I Actual } \\
2 \text { Predicted by Model } \\
3 \text { Predicted If HBCU Slots Increase } \\
4 \text { Change (row } 3 \text { minus row } 2)^{b}\end{array}$ & $\begin{array}{r}14.1 \\
14.1 \\
19.9 \\
5.8\end{array}$ & $\begin{array}{r}26.2 \\
26.3 \\
20.9 \\
-5.4\end{array}$ & $\begin{array}{r}17.8 \\
17.7 \\
16.1 \\
-1.6\end{array}$ & $\begin{array}{r}41.9 \\
41.9 \\
43.0 \\
1.1\end{array}$ \\
\hline \multicolumn{5}{|c|}{$\begin{array}{c}\text { Panel B } \\
\text { Bottom-Quartile Test Score }\end{array}$} \\
\hline $\begin{array}{l}\text { I Actual } \\
2 \text { Predicted by Model } \\
3 \text { Predicted If HBCU Slots Increase } \\
4 \text { Change (row } 3 \text { minus row } 2 \text { ) }\end{array}$ & $\begin{array}{r}11.3 \\
10.6 \\
15.0 \\
4.4\end{array}$ & $\begin{array}{r}16.1 \\
17.0 \\
13.1 \\
-3.9\end{array}$ & $\begin{array}{r}20.3 \\
20.4 \\
18.4 \\
-2.0\end{array}$ & $\begin{array}{r}52.3 \\
52.0 \\
53.5 \\
1.5\end{array}$ \\
\hline \multicolumn{5}{|c|}{$\begin{array}{c}\text { Panel C } \\
\text { Bottom-Quartile Family Income }\end{array}$} \\
\hline $\begin{array}{l}\text { I Actual } \\
2 \text { Predicted by Model } \\
3 \text { Predicted If HBCU Slots Increase } \\
4 \text { Change (row } 3 \text { minus row } 2 \text { ) }\end{array}$ & $\begin{array}{r}15.2 \\
14.3 \\
20.0 \\
5.7\end{array}$ & $\begin{array}{r}20.4 \\
18.9 \\
14.5 \\
-4.4\end{array}$ & $\begin{array}{r}16.6 \\
17.2 \\
15.3 \\
-1.9\end{array}$ & $\begin{array}{r}47.8 \\
49.6 \\
50.2 \\
0.6\end{array}$ \\
\hline
\end{tabular}

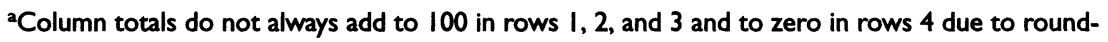
ing errors.

'Authors' computations from multinomial logit model estimates (which are available from the first author) and the values of the explanatory variables for each individual (save that SLOTS is set equal to zero for individuals in states without any HBCUs and individuals from all states are included in the estimation).

The results are reported in Table 9.6. A comparison of rows A1 in Tables 9.3 and 9.6 indicates that the overall college enrollment rate of 58.1 percent in this all-state sample was higher than the overall enrollment rate of 55.2 percent in the HBCU state sample. Both the four-year college enrollment rate (the sum of four-year HBCU and four-year other) and the twoyear college enrollment rate were also slightly higher in the overall sample. A comparison of row A1 with row A2, which contains the predictions using the actual values of the explanatory variables for each individual, indicates that the model predicts well within the sample. 
The conceptual experiment that we conduct to simulate the effects of increasing SLOTS in this model is again to increase SLOTS faced by each individual by its standard deviation in the sample of high school graduates from HBCU states, holding all other variables constant. That is, we predict how the enrollment probabilities would change for each individual if we increased SLOTS in the state. For high school graduates from non-HBCU states, this is equivalent to creating HBCUs in their states.

The results appear in row A4 of Table 9.6 and are very similar to those found in the corresponding row of Table 9.3. We predict that an increase in SLOTS again increases enrollment at four-year HBCUs. However, this increase again comes almost entirely at the expense of lower enrollments at other four-year and two-year colleges. We report results from simulations for students with lower test scores or lower family incomes in panels B and C of Table 9.6, and they tell the same story.

\section{Concluding Remarks}

The evidence we have presented in this paper, using data from both NLS72 and HSB, suggests that the availability of slots at HBCUs for African American high school graduates does influence their college enrollment behavior. Other factors held constant, we predict that an increase in the number of full-time equivalent undergraduate enrollments at four-year HBCUs in a state relative to four times the number of African American high school seniors in the state will increase the probability that an African American high school graduate enrolls in a four-year HBCU. However, this does not increase the probability that more students will be enrolled in college in general, because all of the increased enrollment at HBCUs appears to come from students who otherwise would have been enrolled in two-year or other four-year colleges. Put another way, HBCUs appear to influence where African Americans go to college, not whether they go to college.

It is well known that students who initially enroll in two-year colleges are much less likely to receive four-year college degrees than students who initially enroll in four-year colleges. Moreover (as we have shown previously), other factors held constant,-African American four-year college students who enroll in HBCUs have higher graduation probabilities than those who enroll in other four-year colleges (Ehrenberg and Rothstein 1994). Hence, the availability of slots at HBCUs does enhance the probability that African American high school graduates will receive college degrees. However, the evidence on whether this enhanced educational success is matched by enhanced labormarket success is mixed (Constantine 1995; Ehrenberg and Rothstein 1994).

Proponents of HBCUs often argue that they play a unique role in the education of educationally and economically disadvantaged students. We 
found no evidence, however, that the availability of slots in HBCUs affects the college enrollment choices of educationally and economically disadvantaged youths differently than it does other African American youths.

The bottom line of our discussion is that a reduction in enrollment in African American youths at HBCUs because of higher state-imposed admission standards may, in the short run, simply lead these students to enroll instead in two-year colleges rather than not enrolling in college at all. However, unless new remedial programs are developed that enable students to qualify directly for other four-year colleges, African American youths' four-year college enrollment rates are likely to decline. Furthermore, the net effect of such enrollment shifts will likely be to decrease the proportion of African American youths who receive four-year college degrees. It is an open question whether, in the longer run, improvements in high school curriculum induced by the higher college admission standards will lead to higher college enrollment and graduate rates for African American youths in these states.

The renewed interest in the role of HBCUs in southern states comes at the same time that courts are deciding whether to restrict the use of race in admissions decisions. A federal appeals court decision in the Hopwood case (which dealt with the University of Texas law school), as well as a vote by the University of California Regents followed by a public referendum in California, have barred the use of race in admissions decisions in public universities in California, Texas, and several other states. A recent suit against the University of Michigan seeks to achieve the same result in that state. Clearly, serious analyses are required to determine whether such restrictions influence where underrepresented minorities go to college, their college graduation rates, and whether they attend college at all. ${ }^{12}$

12 Underrepresented minority enrollments plunged at both the Berkeley and Texas law schools in the first year after these restrictions went into effect, but analyses have yet to be undertaken as to whether aggregate minority enrollments in all law schools in these states also fell. 